\title{
MAQUIAVEL E O CONCEITO DE LIBERDADE EM TRESS VERTENTES DO NOVO REPUBLICANISMO*
}

\section{Ricardo Silva}

\section{Introdução}

Não é nova a interpretação que apresenta o pensamento político de Maquiavel como o mais notável exemplar do ressurgimento da concepção republicana de liberdade. Já em meados do século XVI, poucas décadas depois da morte de Maquiavel, Giovani Busini, um republicano opositor dos Médici, retratava-o como "o mais extraordinário amante da liberdade” (apud Baron, 1961, p. 217).

* Versão anterior deste artigo foi apresentada no 32 ${ }^{\circ}$ Encontro Anual da Anpocs. Sou grato aos coordenadores e participantes do GT Teoria Política: além da democracia liberal?. Agradeço também aos colegas do NEPP/UFSC, especialmente a Gustavo Althoff, pelas discussóes em torno do tema deste artigo e pelo auxílio na tradução das citações.

Artigo recebido em novembro/2008

Aprovado em dezembro/2009
Um século mais tarde, escritores como James Harrington e John Milton chamavam a atenção para as preferências republicanas do autor dos Discorsi, ao mesmo tempo em que se inspiravam em suas liçôes para a justificação das pretensões do parlamento contra a coroa no contexto revolucionário inglês. No século das luzes, poucos anos antes da eclosão da Revolução Francesa, Rousseau dava ainda mais ênfase à integridade republicana de Maquiavel, afirmando que mesmo em $O$ Príncipe, sua obra aparentemente mais pró-monárquica, o autor, "fingindo dar liçôes aos reis, deu-as ele, e grandes, aos povos" (Rousseau, s/d, p. 78). ${ }^{1}$

Contudo, ao longo de quase cinco séculos, a interpretação republicana do pensamento político de Maquiavel jamais foi forte o bastante para se sobrepor ao retrato convencional, que chega a apresentar o florentino como um dos mais inescrupulosos conselheiros de tiranos de todos os tempos. Tal visão do sentido moral e político das idéias de 
Maquiavel enraizou-se firmemente no solo do senso comum, e no contexto acadêmico de meados do século XX pôde contar com o endosso enfático de influentes teóricos. Para Leo Strauss, por exemplo, a imagem mais correta do "blasfemo" Maquiavel seria mesmo a de um "professor do mal" (Strauss, 1958, p. 9).

Foi somente a partir da segunda metade do século passado que (ao menos nos meios acadêmicos) o "filósofo da liberdade" começou a ganhar reconhecimento em detrimento do "conselheiro de tiranos". Impulsionada inicialmente pela publicação de estudos no campo da história do pensamento político, a interpretação republicana de Maquiavel passou a insinuar-se também no campo da teoria política normativa. Vertentes influentes do atual republican revival na teoria política vêm reivindicando a herança de Maquiavel, ao mesmo tempo em que vêm oferecendo novos elementos para a releitura dos seus textos. ${ }^{2}$ Outra hierarquia vem sendo reivindicada para o conjunto da obra maquiaveliana. O Príncipe já não aparece mais como a visão autorizada dos ideais políticos do autor, e obras outrora menos freqüentadas e valorizadas, como a História de Florença e, sobretudo, os Discorsi, vêm passando para o primeiro plano das exegeses.

Observado de longa distância, o Maquiavel republicano parece íntegro o bastante para começar a se sobrepor ao Maquiavel das vilanias principescas. Porém, visto mais de perto, o novo Maquiavel perde foco e nitidez. Se há acordo entre os neo-republicanos sobre o fato de que o pensamento de Maquiavel se orienta pela defesa do ideal da liberdade, há, contudo, inúmeras discordâncias sobre o significado do próprio conceito de liberdade por ele adotado, bem como sobre a natureza das formas institucionais que constituem e asseguram a liberdade numa república. Em que consiste, afinal, o núcleo do republicanismo maquiaveliano?

Neste artigo, examinaremos três tipos de respostas para esta questão. Primeiramente, examinaremos a interpretação que advoga que o núcleo do republicanismo de Maquiavel consiste no alinhamento do autor com uma concepção positiva de liberdade, um modo de conceituar a liberdade inspirado em Aristóteles e em seus "seguidores" romanos, como Cícero e Salústio. Intérpretes como
Hans Baron e John Pocock contribuíram decisivamente para essa maneira de conceber o princípio constitutivo do republicanismo de Maquiavel.

Em seguida será examinada a interpretação que parte do princípio de que Maquiavel era, na verdade, mais cético acerca da disposição dos cidadãos para o comportamento virtuoso do que as interpretações de Baron e Pocock nos fazem supor. Autores como Quentin Skinner, Maurizio Viroli e Philip Pettit detêm-se na demonstração de que a idéia de liberdade adotada por Maquiavel, longe de equivaler à concepção positiva dos neo-atenienses, representava uma modalidade de liberdade negativa, inspirada na herança constitucional da antiga Roma. Porém, em contraste com as vertentes dominantes da tradição liberal, a concepção de liberdade negativa dos republicanos "neo-romanos" não aceita a oposição entre liberdade e lei. Pelo contrário, afirmam que as boas leis são imprescindíveis para a constituição e a manutenção da liberdade, e que esta teria sido a crença fundamental do republicanismo maquiaveliano.

Por fim, investigaremos um tipo de resposta à nossa questão que procura radicalizar o elemento democrático (popular) do republicanismo de $\mathrm{Ma}$ quiavel. Em uma série de estudos recentes, John McCormick vem argumentando que mais do que uma teoria da república como o império da lei, há, em Maquiavel, uma "teoria da democracia” apropriada para restabelecer a accountability nas repúblicas democráticas contemporâneas; uma teoria da democracia equipada para superar as limitações das teorias dominantes, tanto nas versões liberais e minimalistas, como nas versões participativistas e comunitaristas.

Examinaremos mais detalhadamente essas três leituras de Maquiavel, partindo da hipótese de que a comparação entre elas, além de revelar evidências textuais e contextuais enriquecedoras de nossa compreensão histórica das idéias de um autor clássico, representa um procedimento que nos remete inevitavelmente a debates centrais na teoria política contemporânea. Em que pese nossa convicção sobre as vantagens do casamento entre a história intelectual e a teoria política, diríamos, em benefício da precisão, que a orientação aqui subjacente não é a do historiador das idéias, que se perguntaria o que $\mathrm{Ma}$ - 
quiavel "estava fazendo" ao escrever seus textos (cf. Skinner, 1988). A orientação é outra, embora, em certo sentido, a pergunta seja a mesma: $\mathrm{O}$ que os historiadores e teóricos do neo-republicanos estão fazendo ao interpretarem a herança de Maquiavel?

\section{A virtude dos cidadãos}

De modo geral, o Maquiavel "conselheiro de tiranos" aparece em interpretaçôes que tomam as máximas contidas em $O$ Príncipe como foco de atenção. Por outro lado, o Maquiavel republicano é quase sempre aquele que os intérpretes encontram nos Discursos sobre a primeira década de Tito Livioos Discorsi. Não por acaso, uma das estratégias dos intérpretes republicanos de Maquiavel consiste em minimizar a importância do livro de espelho para príncipes e salientar a importância do livro dedicado ao estudo das repúblicas. Não se trata de uma estratégia de simples execução, uma vez que a celebridade de Maquiavel deve-se, incomparavelmente, mais à recepção de $O$ Príncipe do que à recepção de qualquer outra de suas obras. Tal estratégia argumentativa envolve um esforço de contextualização que se reflete até mesmo em disputas acerca da correta datação dos textos maquiavelianos.

As interpretações que atribuem uma identidade monarquista - e mesmo tirânica - às idéias de Maquiavel costumam referir-se aos Discorsi à sombra de $O$ Príncipe, obscurecendo diferenças essenciais entre as duas obras e apresentando ambas como frutos de uma mesma intenção ou doutrina. Mesmo quando são reconhecidas as distinçôes, tentase demonstrar que a composição dos Discorsi (ou de parte deles) antecede cronologicamente a de $O$ Principe. Chabod, por exemplo, em livro originalmente publicado em 1922, sugere que "se pode tomar como certo que, à época em que Maquiavel começou a trabalhar em $O$ Príncipe, o primeiro livro dos Discorsi já estava, em grande medida, finalizado (Chabod, 1958, p. 31). Maquiavel teria começado a escrever o livro sobre as repúblicas no verão de 1513, interrompendo a redação quando novas experiências lhe revelaram a inutilidade da manutenção de fortes compromissos republicanos no contexto de corrupção e decadência em que se encontrava Florença. A interrupção da redação dos Discorsi teria sido imediatamente seguida da composição de $O$ Príncipe, ocorrida no segundo semestre do mesmo ano de 1513.

Esses meses - de julho a dezembro - testemunham o nascimento do tratado De Principatibus, por nós conhecido como $O$ Príncipe. As notas marginais sobre Lívio são deixadas de lado. Na última delas, incidentalmente, já podemos discernir uma atitude mental pouco usual. Encontramos dois ou três capítulos inteiros em que o povo, que constitui o espírito vivo dos Discorsi, é substituído pelo indivíduo solitário, enquanto o heróico conflito de classes e de partidos se transforma no conflito interno de um homem cujos pensamentos ninguém pode conhecer (Idem, p. 12).

Somente alguns anos mais tarde, Maquiavel retomaria a redação do livro sobre as repúblicas, num tom bem menos exaltado do que aquele que marcou a escritura dos primeiros capítulos. A conclusão que se depreende da hipótese de Chabod é a de que $O$ Príncipe é a obra que representa o momento mais desenvolvido e maduro do pensamento político de Maquiavel, ao passo que os Discorsi seriam o resultado de um conjunto de "notas marginais", escritas em diferentes épocas e sob o impulso de diferentes motivaçôes. Quando confrontado com a realidade e as exigências de sua própria época, $\mathrm{Ma}$ quiavel interrompe o elogio do passado de grandeza e liberdade da Roma antiga e volta-se para a busca de soluçôes mais "realistas".

Deve-se a Hans Baron a contestação mais convincente da influente tese de Chabod para o estabelecimento das datas de composição das duas principais obras de Maquiavel. Não há dúvida, segundo Baron, sobre o fato de $O$ Príncipe ter sido escrito no ano de 1513. Mas não passaria de uma suposição equivocada, ainda que engenhosa, a sugestão de Chabod de que parte dos Discorsi fora escrita antes disso. O fato de Maquiavel fazer referência a uma obra sobre repúblicas no segundo capítulo da edição de $O$ Príncipe não significa necessariamente que os Discorsi - ou parte deles - estivessem prontos em 1513. Baron procura reunir evidências e fundamen- 
tar conjecturas que nos levam a crer que a famosa passagem na qual Maquiavel ressalta que não tratará das repúblicas, uma vez que já teria, "em outra ocasiāo", discorrido "longamente sobre o assunto" (Maquiavel, 1998, p. 5), foi inserida em O Príncipe entre 1515 e 1518 , e não no ato de composição original da obra, em 1513. O objetivo de Baron é demonstrar que, ao contrário do que supõem os intérpretes que tomam Maquiavel como um conselheiro de príncipes, a versão mais desenvolvida e madura das idéias políticas do autor aparece não no livro sobre os principados, mas nos Discorsi, uma vez que "no caminho de $O$ Príncipe até os Discorsi, novas experiências fizeram parte de sua vida [...], o horizonte de sua mente se expandiu com os anos, como a de todo pensador grande e criativo". Desse modo, "se aceitarmos que todos os três livros dos Discorsi foram subseqüentes a $O$ Príncipe, o realismo político do panfleto, muito longe de ser o segundo passo, ou mesmo o clímax no desenvolvimento de Maquiavel, em verdade, representa uma fase anterior"(Baron, 1961, p. 250).

A disputa pelo estabelecimento das datas de composição das obras de Maquiavel não é mera minudência de uma historiografia de antiquário. Ela é parte importante da disputa mais ampla pelo estabelecimento da identidade do pensamento político do autor. Conselheiro de príncipes ou republicano? Cada uma dessas interpretações contrastantes propõe sua própria hierarquização da obra, destacando determinados livros em detrimento de outros, ou determinadas partes de um mesmo livro em detrimento de outras. Ao sugerir que é nos primeiros capítulos de cada um dos três livros dos Discorsi que se encontra a visão mais acabada do pensamento político de Maquiavel, Hans Baron procura fornecer elementos para a interpretação republicana. Nesses capítulos encontrar-se-ia a forma mais decantada das liçóes tiradas dos estudos de Maquiavel depois da redação de $O$ Príncipe. De acordo com Baron, o exílio a que Maquiavel se viu forçado após a queda do governo republicano ofereceu-lhe a oportunidade de uma dedicação plena à investigação dos grandes clássicos da antiguidade, bem como dos humanistas do renascimento italiano, especialmente os do século XV. O contato sistemático com essas fontes teria fornecido ao autor dos Discorsi os instrumentos intelectuais para formular, em mais elevado nível, seu ideal político, um ideal que se alimentava da reflexão sobre sua própria experiência pregressa de funcionário da república florentina. Mas também um ideal que, recorrendo ao passado, projetava-se para o futuro.

Baron interpreta Maquiavel não apenas como um partidário do republicanismo, mas também como um autor plenamente imerso na cultura do humanismo cívico italiano. O panorama retratado pelo historiador alemão fornece uma visão essencialmente política do Renascimento. O humanismo cívico é situado no centro da cultura que passa a se expandir desde o século XIV, intensificando-se e ganhando contornos mais nítidos quando se inicia, principalmente em Florença, a luta contra a expansão de principados tirânicos. Sendo o palco do ressurgimento de um conjunto de valores clássicos associados ao republicanismo, a Florença da virada do século XIV para o século XV viu surgir uma nova vaga de interesse em clássicos como Aristóteles e, principalmente, Cícero, cuja influência no movimento intelectual do renascimento é enfatizada por Baron. O principal legado desses clássicos da antiguidade para os humanistas do renascimento italiano teria sido a lição de que a plena realização da humanidade dos indivíduos só seria possível mediante a participação desses indivíduos - qua cidadãos - nos assuntos públicos. Desse modo, "sem mentes que se mostrassem em acordo quanto aos valores e ideais da vita activa et politica dos cidadãos Gregos e Romanos, o humanismo cívico não poderia ter surgido" (Baron, 1966, p. 112). Se ao longo do século XIV o humanismo cívico aparecia ainda com ambigüidades e limitações em textos de pensadores como Petrarca e Salutati, no século seguinte ele assumiria uma forma bem mais desenvolvida e consistente nos textos de Leonardo Bruni. Para Baron, é no republicanismo do século XV, e especialmente na obra de Bruni, que o ideal da vida ativa assume clara predominância em relação ao ideal da vida contemplativa, professada pela escolástica medieval e problematicamente assumida por muitos humanistas do século XIV.

Embora Leonardo Bruni seja o grande protagonista da narrativa de Baron, este pressentiu que, sem Maquiavel, a história do humanismo cívi- 
co perderia muito de seu potencial interesse para a atualidade. Assim, Baron advoga que "o que se alcançara" por volta de meados do século XV "reemergeria e, em algum momento, remodelaria a conduta e o pensamento dos cidadãos Florentinos, quando, no tempo de Savonarola, Maquiavel, Francesco Guicciardini e Donato, a República fosse restaurada" (Baron, 1966, p. 439).

Mas o Maquiavel que emerge da interpretação de Baron é talvez próximo demais da tradição do humanismo cívico. É aquele que procura a fonte do poder político "na criação de uma tessitura social e constitucional que permitisse o desenvolvimento de energias cívicas, e de um espírito de devoção e sacrifício político, em todas as classes do povo" (1961, p. 249). Conforme observou com acuidade John Najemy (1996), o esforço de Baron para trazer Maquiavel para o leito do humanismo cívico apoiou-se na pressuposição da "pureza ética" de um pensador confiante no espírito de "devoção e sacrifício" de seus concidadãos. Assim, Baron acabou negligenciando aquelas dimensões do pensamento de Maquiavel que revelam seu afastamento da tradição do humanismo cívico. De modo mais relevante, fica de fora da interpretação de Baron a análise do autor dos Discorsi acerca da natureza do conflito social e de suas conseqüências institucionais. Além disso, Baron negligencia a contundente crítica de Maquiavel à aristocracia florentina, bem como suas idéias sobre temas como a manipulação da religião e a corrupção da ordem institucional e dos costumes na república. O fato é que a avaliação maquiaveliana da República Florentina do século XV era demasiadamente crítica para adequar-se ao tom laudatório do republicanismo de Bruni e de outros humanistas cívicos, alvos das atenções de Baron. Não é por acaso que jamais escreveu mais do que poucas frases sobre a História de Florença, obra na qual Maquiavel critica abertamente o tratamento dispensado pelos "excelentes historiadores" Leonardo Bruni e Poggio Bracciolini ao que teria sucedido com Florença até o ano de 1434. Conforme as palavras de Maquiavel,

[...] depois de ler diligentemente seus escritos $[. .$.$] , percebi que foram muitíssimo dili-$ gentes na descrição das guerras travadas pelos florentinos contra os príncipes e povos estrangeiros, mas que, no que se refere às discórdias civis e às inimizades internas, bem como aos seus efeitos, eles calaram de todo uma parte e descreveram a outra com tanta brevidade que nela os leitores não podem encontrar utilidade nem prazer algum (2007b, p. 7).

Apesar dos excessos de Baron em sua tentativa de enquadrar as idéias do autor dos Discorsi na tradição do humanismo cívico, as pesquisas desse autor abriram as portas para investigaçôes mais matizadas. Aptas a reconhecerem as inovações de Maquiavel em relação a seus predecessores humanistas, tais investigaçôes não deixam, porém, de enfatizar o profundo enraizamento do republicanismo maquiaveliano na tradição clássica (aristotélica) do governo misto cum cidadania ativa. Vejamos o exemplo de J. G. A. Pocock. ${ }^{3}$

Se Baron renovou o interesse no republicanismo ao demonstrar a centralidade do humanismo cívico na cultura do Renascimento, Pocock procura realizar um intento ainda mais ambicioso, reconstruindo a tradição republicana desde sua re-emergência no Renascimento italiano até suas ulteriores manifestaçôes no mundo moderno. Na narrativa de Pocock, após ressurgir com os humanistas cívicos, o republicanismo manifestou-se no século XVII nas elaboraçôes de pensadores comprometidos com a causa da liberdade no processo da revolução inglesa; e esses discípulos anglófonos de Maquiavel - James Harrington à frente - serviram como fonte de inspiração, um século depois e do outro lado do Atlântico, para o amplo movimento de idéias associado à revolução norte-americana. $\mathrm{O}$ "momento maquiaveliano" isolado por Pocock vem contribuindo para minar as bases da narrativa dominante sobre as origens ideológicas do modelo constitucional norte-americano, narrativa que advoga uma inspiração "liberal" do movimento revolucionário. ${ }^{4}$ Essa contribuição explica a grande repercussão do estudo de Pocock na historiografia norte-americana (Rodgers, 1992).

O que Pocock chamou de "momento maquiaveliano" não é algo que se refira exclusivamente às idéias e ao contexto de Maquiavel. De Aristóteles a Petrarca, de Bruni a Guicciardini e Donato Gian- 
notti, de Harrington a Madison, a gama de pensadores que aparecem associados ao referido "momento" é numerosa. Conforme esclarece Pocock, “o 'momento maquiaveliano' é uma expressão que deve ser interpretada de duas maneiras. Em primeiro lugar, ela denota o momento, e a maneira, em que o pensamento Maquiaveliano fez sua aparição". Em segundo lugar,

[...] é um nome para o momento, num tempo conceitualizado, em que a república era vista em confronto com sua própria finitude temporal, como tentando permanecer moral e politicamente estável num fluxo de eventos irracionais concebidos como essencialmente destrutivos de todos os sistemas de estabilidade secular. Na linguagem que fora desenvolvida para esse propósito, se falava disso como o confronto da "virtude" com a "fortuna" e a "corrupção” (1975, pp. vii-viii).

Mas na interpretação de Maquiavel promovida por Pocock é a idéia de virtude que ocupa o lugar mais proeminente. Se a fortuna representa a contingência dos fenômenos políticos e a corrupção o resultado inevitável - embora mais ou menos acelerado - da ação do tempo sobre a ordem política, a virtude é concebida como a capacidade humana de operar de modo criativo sobre os dados da fortuna. Contudo, diferentemente da tradição medieval, que concebeu a virtude como a capacidade pela qual "o homem bom impunha forma sobre sua fortuna”, o humanismo cívico, "ao identificar o homem bom com o cidadão, politizou a virtude e tornou-a dependente da virtude dos outros" (Pocock, 1975, p. 157).

Pocock é enfático ao afirmar a inspiração aristotélica do conceito de virtude cívica do humanismo renascentista. Sua leitura da Política de Aristóteles fornece-lhe o princípio constitutivo do "momento maquiaveliano". ${ }^{5}$ A virtude cívica é definida como a capacidade de cada cidadão agir em conformidade com o interesse público, ainda que em detrimento de seu interesse particular. "A república, ou a comunidade política, era [...] uma estrutura virtuosa: era uma estrutura em que a capacidade de cada cidadão de colocar o bem comum antes do seu próprio bem era a precondição de todos os outros" (Idem, p. 184). É claro que a constituição de tal "estrutura de virtude" não é nada trivial. É verdade que agindo em conformidade com o bem público, os cidadãos realizam sua essência universal: "A cidadania era uma atividade universal, a polis uma comunidade universal". Mas os cidadãos não eram idênticos como seres particulares, uma vez que "cada um tinha suas próprias prioridades no que tange aos bens particulares que poderia escolher perseguir, e cada um deles encontrava-se ligado por categorias particulares com aqueles que compartilhavam uma, algumas, ou todas de suas prioridades"(Idem, p. 68). A questão que se põe do ponto de vista constitucional é a de como fazer com que essa diversidade de concepções particulares de bem se harmonize com o bem comum.

Segundo Pocock, Aristóteles não acreditava que a atividade do cidadão pudesse ser concebida isenta de relaçôes com a atividade dos indivíduos particulares. Não é possível separar o cidadão do indivíduo particular do mesmo modo que não é possível separar quem governa de quem é governado. A condição que tipifica a cidadania é justamente aquela em que governante e governando se encontram no mesmo indivíduo: "o universal e o particular encontraram-se no mesmo homem" (Idem, ibidem); e se os cidadãos inevitavelmente assumem uma personalidade social ao perseguirem seus fins particulares, isso deve modificar sua capacidade para participar "na atividade universal de se tomar decisões voltadas para a distribuição do bem comum". Em vista disso, Pocock conclui que, na teoria política de Aristóteles, "o problema a confrontar a polis tornou-se o de distribuir o exercício particular dessa função universal de maneira tal que se relacionasse com a diversidade de personalidades sociais que os cidadãos exibiam como resultado de suas prioridades guiadas por valores individuais" (Idem, ibidem).

Tal problema poderia ser resolvido atribuindose a cada segmento de elite dos diferentes setores sociais, inclusive à elite da não-elite, funções específicas no processo global de tomada de decisões na cidade, funções designadas de acordo com a capacidade e a aptidão específicas de cada setor. $\mathrm{O}$ fundamental é a garantia de que nenhum dos setores sociais se encontre em condição de impor suas 
prioridades particulares sobre o universal, pois no modelo aristotélico, conforme Pocock, "qualquer forma de governo em que o bem de um grupo particular fosse tratado como idêntico ao bem do todo era despótico, mesmo se o bem particular pudesse ser, ao menos inicialmente, um bem real em si" (Idem, p. 73). Somente uma estrutura institucional mista, concebida para gerar o equilíbrio entre as diferentes preferências dos diversos setores, poderia assegurar a manutenção da "estrutura de virtude" da república.

Pocock preocupa-se em discutir a idéia de virtude nos dois principais livros de Maquiavel, mas esclarece que em $O$ Príncipe ele lida com o problema das virtudes requeridas pelo "príncipe novo" para dar forma a uma ordem política ainda inexistente ou já corrompida. No entanto, a virtù requerida do príncipe novo não é do mesmo tipo daquela requerida dos cidadãos ordinários que já vivem em liberdade sob uma ordem republicana. Mesmo assim, é preciso ter claro que, para Maquiavel, o êxito do príncipe em sua empreitada fundadora não pode prescindir de certo tipo de virtude da parte do povo. Maquiavel é pródigo em expressar seu profundo desprezo pelas tropas mercenárias. $\mathrm{O}$ príncipe novo estaria sempre mais bem guarnecido se pudesse confiar a guarda do stato ao próprio povo armado. O príncipe novo seria alguém de grande virtude militar. No limite, seu sucesso em fundar e manter o Estado estaria vinculado à sua capacidade de inspirar este mesmo tipo de virtude no povo. É verdade que a virtude militar não se identifica com a virtude cívica, mas, conforme sustenta Pocock, uma não subsiste sem a outra na mente de Maquiavel.

Embora a idéia de virtude cívica esteja de certo modo implícita na reflexão levada a efeito em O Príncipe, é nos Discorsi que a compreensão de Maquiavel sobre o conceito é elaborada em sua plenitude. Referindo-se a duas dimensōes do conceito de virtude, Pocock assinala que:

Por meio da institucionalização da virtude cívica, a república, ou polis, sustenta sua própria estabilidade ao longo do tempo e desenvolve o material humano bruto que a compõe na direção daquela vida política que é a finalida- de da humanidade. Por meio do exercício de uma virtù parcialmente não-moral, o inovador impõe a forma sobre a fortuna: isto é, sobre a seqüência de acontecimentos desordenada por seu próprio ato ao longo do tempo. Nos Discorsi de Maquiavel [...], ambos os conceitos convergem (Idem, pp. 183-184).

Nos Discorsi estariam evidentes as relações entre a virtude cívica e a virtude militar. ${ }^{6} \mathrm{O}$ ponto central da análise maquiaveliana, de acordo com Pocock, reside na idéia de que a virtude militar seria o veículo para se passar da massa popular a uma comunidade de cidadãos ativos, alimentando o sentimento cívico necessário ao florescimento da liberdade e da grandeza da república. É nesta chave que Pocock interpreta a célebre declaração de Maquiavel de que em uma república expansiva deve-se confiar ao povo a "guarda da liberdade" (Maquiavel, 2007a, p. 24). Maquiavel teria em mente a disposição do povo para lutar em exércitos pela defesa da pátria. A guerra em defesa da pátria seria a arena privilegiada de realização do tipo de virtude que a república demandaria do cidadão comum. ${ }^{7}$

\section{Os conflitos e as leis}

Os estudos de Baron e Pocock abriram uma ampla avenida de investigação sobre a tradição do humanismo cívico. Além disso, contribuíram para o estabelecimento de uma identidade republicana para Maquiavel, não apenas por meio de declarações ocasionais, como ocorreu muitas vezes no passado, mas pela mobilização de intenso esforço de pesquisa e contextualização das idéias do pensador florentino. É impossível não reconhecer que os desenvolvimentos recentes no estudo do republicanismo de Maquiavel sofreram forte influência de seus achados.

Não obstante a força de tal influência, as interpretações do republicanismo que se beneficiaram dos trabalhos desses autores seguiram suas próprias trajetórias. Dentre tais interpretaçōes, destaca-se aquela desenvolvida por estudiosos do republicanismo que vêm trabalhando sob a liderança de Quentin Skinner. Este, ao lado do próprio Pocock, é um dos expoentes do referencial metodológico para o 
estudo da história do pensamento político associado à chamada "Escola de Cambridge". ${ }^{8}$

Skinner vem recuperando a tradição republicana em moldes distintos daqueles propostos por Baron e Pocock, apresentando o pensamento de Maquiavel como extensivo à sua interpretação. Para Skinner, o renascimento do republicanismo nos primórdios da modernidade deveu-se mais à recuperação de moralistas romanos, como Cícero e Salústio, do que à retomada da concepção aristotélica das virtudes cívicas. É certo que nos estudos de Baron e Pocock os referidos pensadores romanos aparecem recorrentemente. Contudo, eles aparecem como seguidores da concepção aristotélica de cidadania. O que Skinner sustenta é que o republicanismo romano, embora não alheio à concepção grega de cidadania, deve ser pensado como uma tradição intelectual e política independente. Se na interpretação cívico-humanista o centro das atençôes era a noção de virtude cívica, na interpretação "neo-romana" de Skinner o foco da análise deslocase para a arquitetura institucional do Estado.

Esse deslocamento do foco analítico foi acompanhado de um esforço de investigação sobre a história do conceito de liberdade. Sustentar a independência do republicanismo "neo-romano" em relação à tradição aristotélica requer uma concepção de liberdade distinta daquela presente no modelo ateniense, com o qual opera Pocock, que não esconde a influência de Hannah Arendt em seu próprio esforço de reconstituição da tradição republicana (Pocock, 1975, p. 550). Ressalte-se que poucos autores do século XX fizeram tanto quanto Arendt para restabelecer os laços entre participação política e liberdade, atualizando a perspectiva aristotélica. Para Arendt, "o sentido da política é a liberdade" (1999, p. 38), e a liberdade de uma pessoa consiste exatamente no exercício da sua participação na comunidade política. A liberdade reside na ação, no ato de iniciar algo novo.

Skinner parece não se sentir muito confortável com as conseqüências "comunitaristas" do modelo neo-ateniense, organizado em torno de uma visão enfaticamente "positiva" de liberdade. Prefere assumir uma posição polêmica, caracterizando a liberdade republicana à la Maquiavel como um tipo de "liberdade negativa", uma liberdade desfrutada tanto por indivíduos como por coletividades para perseguirem os fins por eles próprios escolhidos. "Estar de posse da própria liberdade é ser livre no sentido 'negativo' ordinário de não se estar constrangido por outros agentes. Portanto, ser livre é - como Maquiavel acrescenta com referência a agentes coletivos - agir 'de acordo com a própria vontade e segundo o próprio juízo" (Skinner, 2002a, p. 197). O autor ressalva que as implicaçōes dessa visão da "liberdade negativa" são muito diferentes das encontradas na concepção liberal atomista. ${ }^{9}$ Skinner não admite o fato de que a liberdade dos particulares possa realizar-se em um contexto de uma comunidade não-livre. Ou seja, sem liberdade política, não pode haver, de modo duradouro, liberdade individual. Daí a necessidade de os indivíduos participarem da vida política da república. Desse modo, Skinner afirma, contra o liberalismo, que a postulação de uma completa desvinculação entre liberdade individual e liberdade política representa uma grave "falha de racionalidade" (Skinner, 1984, p. 217). Seria como desejar os fins sem recorrer aos meios. Por outro lado, contra o comunitarismo, Skinner afirma que a participação política é precisamente um meio, um instrumento da liberdade, não a própria liberdade. Em relação à liberdade, a participação política seria um valor instrumental, não um valor intrínseco, como quer o modelo neo-ateniense.

Não há dúvida de que, em seu momento inicial, a motivação central de Skinner era invectivar contra a teoria dominante da liberdade, organizada em torno do conceito de "liberdade negativa" tal como definido por Isaiah Berlin. ${ }^{10}$ Todavia, já naquele momento, Skinner mobilizava as idéias de Maquiavel também como alternativa à vertente que conecta o republicanismo à concepção "positiva" de liberdade. Para isso, o primeiro passo do autor foi questionar a tese de que a concepção republicana da liberdade teria sido retomada no Renascimento a partir da recuperação de Aristóteles. Skinner critica a tese de Baron de que o republicanismo teria emergido somente a partir do início do século $\mathrm{XV}$, e que a ideologia da forma eletiva e participativa de governo teria surgido como uma resposta de Florença ao avanço das pretensões autocráticas e imperialistas do regime de Milão. Subjacente à 
tese de Baron, encontrar-se-ia a suposição de que o republicanismo moderno não teria sido possível sem o retorno aos antigos, especialmente a Aristóteles, cuja obra se tornara amplamente acessível em decorrência de traduções realizadas na virada do século XIV para o século XV na Itália. Já em As fundaçóes do pensamento político moderno, publicado em 1978, Skinner chama a atenção para o fato de que muito antes de Aristóteles se tornar amplamente disponível para os humanistas dos séculos XIV e $\mathrm{XV}$, os "pré-humanistas" já haviam descoberto uma maneira de defender as pretensōes das cidades-repúblicas contra as tiranias. Assim, o historiador inglês antecipa em pelo menos dois séculos - de fins do século XIV, como queria Baron, para fins do século XII - a emergência do republicanismo no Regnum italicum. A justificação do regime eletivo e da participação cívica teria dispensado, no momento de sua emergência, o conhecimento da filosofia moral de Aristóteles. Embora não deixasse de se inspirar em fontes da antiguidade, era em Roma, não na Grécia, que se encontrava a fonte de inspiração do republicanismo das cidades italianas.

Tito Lívio, Salústio e, principalmente, Cícero teriam servido de modelos para os republicanos pré-humanistas. Skinner sustenta que "foi dessas humildes origens, muito mais do que devido ao impacto do aristotelismo, que o republicanismo clássico de Maquiavel, Guicciardini, e de seus contemporâneos, descendeu originalmente". Assim, "a teoria política da Renascença, em todas as fases de sua história, deve muito mais profundamente a Roma do que a Grécia” (2002a, p. 92). E não há dúvida de que subjacente a essa conclusão encontra-se a crença de Skinner de que a tradição romana tem uma vida própria, que não pode ser reduzida à herança dos gregos. ${ }^{11}$

É no contexto da tradição romana que o republicanismo de Maquiavel é interpretado por Skinner. Para Maquiavel, assim como para os moralistas romanos e os humanistas cívicos, os mais elevados fins visados por uma cidade seriam a glória e a grandeza cívica. Maquiavel associar-se-ia também à tradição republicana clássica ao assumir que somente por meio de um modo de vida livre e participativo os referidos fins poderiam ser alcançados. Maquiavel "mostra-se satisfeito em adequar suas idéias a uma estrutura tradicional, uma estrutura que se baseia em associar os conceitos de liberdade, bem comum e grandeza cívica de uma maneira amplamente familiar" (Skinner, 1990a, p. 137). Mas o fato, argumenta Skinner, é que Maquiavel compartilha dos ideais do republicanismo clássico introduzindo um conjunto de importantes inovaçōes em tal tradiçãao. ${ }^{12}$

Há dois pontos centrais em que o afastamento de Maquiavel da tradição humanista fica mais evidente. Na visão de Cícero, seguida fielmente pelos humanistas cívicos, as virtudes cardinais necessárias à realização do bem comum são a prudência, a coragem, a temperança e a justiça. Conforme esclarece Skinner, "a análise de Maquiavel difere da de Cícero num ponto imensamente importante. [...] Ele apaga a qualidade da justiça, a qualidade que Cícero, em seu De officiis, descrevera como o esplendor triunfal da virtude" (2002a, p. 207). Essa alteração aparece de modo mais explícito em O Principe, embora também seja perceptível nos Discorsi. $\mathrm{Na}$ análise de Cícero, a justiça consiste em evitar a fraude e a crueldade. Maquiavel não discorda dessa análise no que diz respeito ao conteúdo do conceito de justiça. O que ele nega é que o uso de expedientes fraudulentos ou cruéis seja sempre incompatível com a realização do bem comum. Pelo contrário, há determinadas ocasióes em que tais expedientes são deveras eficazes para a defesa da cidade. Na guerra, por exemplo, a fraude é um método corriqueiro de combate, e em situaçōes em que a liberdade da cidade se encontra ameaçada ou a estabilidade do Estado esteja em risco, a crueldade não pode ser descartada como método de ação.

Outro ponto - ainda mais importante do que o anterior - a marcar o distanciamento de Maquiavel da tradição do republicanismo clássico refere-se ao papel dos conflitos sociais na ordem republicana. Tanto os clássicos romanos quanto os humanistas tendiam a considerar os "tumultos" e os conflitos internos à cidade como graves ameaças à liberdade e à ordem pública. Ainda que esses autores considerassem muitas vezes a necessidade da guerra para proteger a cidade de ameaças externas, a manutenção da paz interna era vista como condição sine qua non da manutenção da liberdade e da persecução do bem comum. Porém, como revela claramente 
a análise maquiaveliana das causas da liberdade desfrutada pela República romana, não somente os conflitos sociais internos não causaram prejuízos à ordem republicana, como consistiram na principal causa do aperfeiçoamento de suas instituições. É com essa convicção em mente que Maquiavel vai "contra a opinião de muitos de que Roma foi uma república tumultuária e tão cheia de confusão que, se a boa fortuna e a virtù militar não tivessem suprido a seus defeitos, ela teria sido inferior a qualquer outra república”. Segue-se então a surpreendente tese segundo a qual "quem condena os tumultos entre os nobres e a plebe parece censurar as coisas que foram a causa primeira da liberdade de Roma”. Para Maquiavel, não apenas em Roma, mas "em toda república há dois humores diferentes, o do povo, e o dos grandes", e "todas as leis que se fazem em favor da liberdade nascem da desunião deles” (Maquiavel, 2007a, p. 21).

As passagens acima são plenas de conseqüências para a interpretação skinneriana de Maquiavel e do republicanismo. Nelas aparece de modo muito nítido a natureza das relações entre conflito social, lei e liberdade: as boas leis são resultados dos conflitos, e a liberdade é resultado das boas leis. $\mathrm{Na}$ análise dos conflitos causadores da liberdade, Maquiavel distingue entre os humores do povo e os das elites, afirmando que estas desejam sempre dominar e expandir seu domínio, enquanto aquele deseja tão-somente a segurança de não ser dominado. De acordo com Skinner, na análise maquiaveliana, tanto as predisposições do povo como as das elites pode levar à corrupção.

Há duas maneiras contrastantes, prossegue Maquiavel, em que essa ameaça da corruzione, essa negação da virtù, tende a surgir. $\mathrm{O}$ conjunto ordinário dos cidadãos tende a ser ozioso, preguiçoso ou inativo; como resultado disso, não conseguem, de modo algum, devotar nenhuma energia a suas obrigações cívicas. Ainda mais perigosa para a liberdade, contudo, é a tendência de cidadãos líderes serem guiados pela ambizione - ambição pessoal. Isso os incita a perverter as instituiçôes livres de suas comunidades de tal modo a favorecer suas próprias famílias e grupos sociais, ao passo que devem, como cidadãos virtuosi, defender os interesses da comunidade como um todo (Skinner, 2002a, p. 164).

Skinner interpreta a análise maquiaveliana sobre os conflitos como um testemunho a favor da organização de uma estrutura institucional destinada a conter a tendência à corrupção inerente às diferentes classes de cidadãos. Tendo em vista o "pessimismo" que o autor detecta em Maquiavel acerca da possibilidade de mudança da natureza corruptível dos indivíduos e dos setores sociais em que estes se agrupam, a única via restante para minorar o problema da corrupção da ordem pública seria a criação de um mecanismo capaz de conter a corrupção ou, pelo menos, neutralizar seus efeitos mais danosos. Tal mecanismo deveria materializarse num determinado conjunto de leis, um sistema constitucional voltado para produzir o tipo de virtude necessária à manutenção da liberdade, virtude que de modo algum brota naturalmente do comportamento dos indivíduos. "O papel indispensável das leis é, portanto, deter-nos da corruzione e impor sobre nós a necessidade de nos comportarmos como cidadãos virtuosi, ao tornar menos tentador seguirmos nossa tendência natural de persecução de nossos próprios interesses às expensas do bem comum" (Idem, p. 174).

O sistema constitucional republicano cumpre dupla função, atuando tanto no sentido negativo, como no sentido positivo, ou seja, tanto na contenção do comportamento corrupto, como na indução do comportamento virtuoso. De um lado, as leis republicanas bloqueiam a tendência à corrupção dos setores sociais mediante a promoção do equilíbrio de poder entre tais setores. $\mathrm{Na}$ medida em que o povo e as elites, com seus diferentes humores, estejam adequadamente representados nas instituições do Estado republicano, cada um desses setores tenderá a exercer sua vigilância sobre o outro. A vigilância mútua serviria como uma espécie de antídoto à ociosidade do povo e à arrogância das elites. De outro lado, a lei teria também a função de "canalizar" o comportamento dos cidadãos para atividades conducentes à realização do bem comum. Num certo sentido, recupera-se aqui a tese de Rousseau de que os cidadãos devem ser "forçados a ser livres". 
Skinner destaca uma passagem em que Maquiavel "resume [...], em termos que nos rememoram da admiração profunda de Rousseau pelos Discorsi", a tese de que o povo "'deve ser acorrentado às leis' se um modo de vida livre há de durar por algum período de tempo" (Idem, p. 174).

Até aqui, é possível concordar com um dos críticos de Skinner (Shaw, 2003), que observa certa ambigüidade na concepção skinneriana de lei. De um lado, ecoando a contragosto a visão positiva de liberdade, Skinner apresenta a lei como uma "agência liberadora”, capaz de transformar a tendência à corrupção em comportamento virtuoso (Skinner, 1983 , p. 13). De outro, o aparato legal assumiria a função de uma "mão invisível", apenas constrangendo a livre fruição do egoísmo constitutivo da espécie humana, sem qualquer possibilidade de alterar essa condição. ${ }^{13}$

Essa tensão interna a uma concepção de lei que remete ora à noção de liberdade positiva ora à noção de liberdade negativa encontra-se, de fato, presente na interpretação skinneriana de Maquiavel. Todavia, a partir do momento em que Skinner desvia o foco de Maquiavel e do Renascimento italiano, e passa a focalizar os desdobramentos da história da concepção republicana de liberdade no contexto inglês do século XVII, a idéia da lei como um aparato institucional gerador de equilíbrio de poder assume preponderância sobre a idéia de lei como agência emancipatória. Isso ajuda a explicar a inflexão de Skinner em direção a uma visão mais jurídica do republicanismo. ${ }^{14}$

Nos artigos sobre Maquiavel, Skinner desejava mostrar que a liberdade republicana é um tipo de liberdade negativa. Com isso ele pretendia afastarse das inclinações comunitaristas que julgava presentes em autores como Pocock - a quem, diga-se de passagem, Skinner tem como exemplo de historiador intelectual. Mas Skinner também não podia simplesmente assumir a concepção liberal clássica de liberdade negativa. Vale lembrar que é exatamente contra o domínio desta concepção que o historiador justifica seu interesse na recuperação da concepção republicana de liberdade. A dimensão institucional da "concepção puramente negativa" (Skinner, 2008) de liberdade é considerada insuficiente para acomodar o ideal republicano. A idéia de que a liberdade consiste unicamente na ausência de coerção beneficiaria uma ordem jurídica fundada exclusivamente na noção de "direitos", sejam estes individuais sejam coletivos. Mas uma república não poderia prescindir de um aguçado senso de "dever" entre seus cidadãos, uma vez que "a menos que coloquemos nossos deveres antes de nossos direitos, temos de esperar que nossos direitos, eles mesmos, sejam debilitados" (Skinner, 1990b, p. 309). É em face desse desejo de se distanciar do liberalismo que Skinner acaba apelando a uma função positiva do papel da lei.

Já em A liberdade antes do liberalismo (1999), Skinner se debruça sobre pensadores ingleses do século XVII, tais como Harrington, Milton e Sidney, herdeiros do republicanismo neo-romano de $\mathrm{Ma}$ quiavel. A partir desse livro, o conceito de liberdade passa a assumir uma conotação mais claramente jurídica, na medida em que é associado ao status de determinado indivíduo na relação com outros indivíduos, com grupos ou com a coletividade. Skinner argumenta que o que caracteriza a tradição neo-romana do republicanismo é a idéia - presente no Digesto das leis romanas - de que um indivíduo pode ser qualificado como livre na medida em que ele não esteja sob a tutela, a dependência ou a vontade arbitrária de outrem. Nas leis romanas, o paradigma da ausência de liberdade é o escravo, aquele que se encontra "sob o poder de outra pessoa" - in aliena potestate sunt.

$\mathrm{Na}$ década de 1990, ao mesmo tempo em que Skinner voltou-se para o tema da liberdade na tradição republicana anglófona, ele passou a contar com a colaboração de autores que, sob sua influência, vêm elaborando, na forma de uma teoria política normativa, uma justificação mais direta da relevância do republicanismo para as sociedades contemporâneas. Dentre tais autores, destacam-se o irlandês Philip Pettit e o italiano Maurizio Viroli. Pettit, principalmente, vem se dedicando ao refinamento analítico do ideal republicano de liberdade, compreendido, como gostaria Skinner, como um conceito negativo. Para o teórico irlandês, ao definir-se pela ausência e não pela presença de algo, a concepção republicana de liberdade associa-se à preocupação liberal de evitar as conseqüências potencialmente ameaçadoras à liberdade individual 
derivadas da noção de liberdade positiva dos teóricos comunitaristas. Contudo, o que deve estar ausente não é a mesma coisa para o republicanismo e para o liberalismo. Enquanto o liberalismo de Berlin enfatiza a ausência de qualquer tipo de interferência intencional de terceiros como o critério da liberdade individual, Pettit destaca que não é qualquer forma de interferência intencional que se revela incompatível com a liberdade republicana, mas exclusivamente aquelas formas de interferência que podem ser qualificadas como arbitrárias. E interferência arbitrária, para o autor, é sinônimo de dominação. Daí a fórmula sintética da liberdade como ausência de dominação, ou, simplesmente, liberdade como não-dominação. Pettit não chegou a tratar com exclusividade o pensamento de Maquiavel, preferindo apoiar-se na contribuição de Skinner. ${ }^{15}$ Contudo, também para o filósofo irlandês, a mobilização da autoridade do florentino é central para a plausibilidade da sua teoria da liberdade como não-dominação:

Maquiavel encontrava-se impregnado de um amor pela Roma antiga e endossou entusiasticamente as idéias de que a liberdade era equivalente a não ser dominado; que a não-dominação somente podia ser alcançada por meio do pertencimento a uma comunidade política em que a res publica ou o bem comum ditava o que acontecia na vida pública; e que tal comunidade política seria caracterizada pelas instituiçôes Romanas, tais como o império da lei, a dispersão do poder e a representação de diferentes classes (Pettit, 1999, pp. 284-285).

O italiano Maurizio Viroli, escrevendo também sob a influência de Skinner, a quem dedica um de seus livros (Viroli, 1992), é atualmente colega de Pettit no departamento de política da Universidade de Princeton. Se Pettit não chegou a se dedicar com exclusividade ao estudo da obra de Maquiavel - talvez devido à predominância dos temas do republicanismo anglófono em sua teoria, especialmente marcada pela experiência constitucional dos Estados Unidos -, Viroli, autor imerso na cultura política do republicanismo italiano, escreveu estudos exaustivos sobre as idéias e as ex- periências do secretário florentino, adotando com renovado entusiasmo a tese do Maquiavel republicano (Viroli, 1990, 1998, 2003). Seguindo o que já havia sido estabelecido por Baron, Pocock e Skinner, Viroli afirma que Maquiavel não pode ser compreendido fora da tradição republicana do humanismo cívico, reconhecendo também a grande inovação do florentino no âmbito da tradição em que ele se inseria, uma inovação manifesta na reavaliação do "valor da concórdia versus o necessário alargamento da base social da cidade" (Viroli, 1990, p. 152). Viroli enfatiza a tese de que, para Maquiavel, a inevitabilidade dos conflitos decorrentes da natureza inclusiva da república romana traria resultados benéficos, desde que tais conflitos fossem devidamente processados no âmbito do acervo institucional do Estado misto. Vê-se, aí, uma vez mais, a centralidade do papel da lei na teoria republicana da liberdade. Para Viroli, aqueles que afirmam que o republicanismo de Maquiavel assenta-se nas virtudes cívicas, em contraposição às leis, estariam perdendo de vista um aspecto central da própria concepção maquiaveliana de virtude cívica. ${ }^{16}$ Conforme argumenta o autor,

[...] o sentido genuíno do tratamento de Maquiavel acerca da virtude política somente pode ser capturado se o lermos vinculando-o ao comprometimento global com o princípio do império da lei do pensador florentino. A virtude política que ele invoca e tenta revitalizar é a energia, a coragem e a habilidade que servem para instituir ou restaurar o império da lei e a vida cívica. Em sua teoria da ação política, o império da lei e a virtude dos fundadores e dos redentores não são mutuamente exclusivos, mas estão integrados um com o outro. A virtude de grandes indivíduos é necessária quando o império da lei ainda está por ser instituído, ou precisa ser restaurado, enquanto a virtude de um povo como um todo é necessária para preservar esse império, se já estiver em vigor. Por esse motivo, interpretar a teoria da virtude política de Maquiavel sem associá-la ao império da lei ignora tanto o sentido de sua interpretação da virtude política, como de seu republicanismo (Viroli, 1998, p. 5). 
Em suma, para autores como Skinner, Pettit e Viroli, o republicanismo de Maquiavel definese primordialmente pela concepção de um marco institucional-legal destinado a gerar equilíbrio e estabilidade na república. Sob esta ótica, o que constitui uma república bem ordenada é antes de tudo a natureza e a eficácia das leis que emanam dos conflitos sociais, e que a eles se interpõem de modo a canalizá-los em benefício da liberdade e do bem comum.

\section{A guarda da liberdade}

Numa série de ensaios recentes, o teórico norte-americano John McCormick vem desenvolvendo uma interpretação do "republicanismo" maquiaveliano que se apresenta como alternativa à interpretação protagonizada pela escola de Cambridge, tanto na versão de Pocock, como na de Skinner e de seus seguidores (McCormick, 1993, 2001, 2003, 2006, 2007). McCormick acusa esses intérpretes de mal compreenderem a sociologia dos conflitos de Maquiavel, mal compreendendo também as implicações constitucionais da concepção maquiaveliana de liberdade. $\mathrm{O}$ resultado disso seria uma interpretação tendencialmente "aristocrática” do republicanismo, a qual não faria justiça à natureza essencialmente democrática das idéias do secretário florentino. Mas o autor afirma também que esse viés aristocrático não é uma peculiaridade do republicanismo da escola de Cambridge, visto que esse traço seria uma constante da tradição republicana como tal. McCormick chega mesmo a lançar dúvidas sobre o valor do "retorno ao republicanismo" como corretivo para as insuficiências da teoria democrática contemporânea. Conforme polemiza: "Estou convencido de que o republicanismo, a menos que seja reconstruído quase que a ponto de desfigurá-lo, só é capaz de reforçar o que há de pior na democracia liberal contemporânea: o poder ilimitado que as elites políticas e socioeconômicas desfrutam às expensas da população em geral" (McCormick, 2003, p. 617). O problema dos intérpretes vinculados à escola de Cambridge não estaria em sua análise da tradição republicana clássica, mas em sua tendência "em mal interpretar
Maquiavel por vias que enfatizam artificialmente sua conformidade com o republicanismo convencional" (Idem, p. 636). Este erro de interpretação resultaria em um amplo conjunto de pontos cegos na visão dos neo-republicanos sobre a obra de Maquiavel. Vale transcrever o sumário desses pontos cegos, uma vez que ele revela, por contraste, o modo como o próprio McCormick compreende o pensamento político de Maquiavel. Os neo-republicanos associados à escola de Cambridge

[...] não especificam suficientemente o papel do conflito de classes na teoria de Maquiavel, com o resultado de que ignoram os meios institucionais pelos quais o povo tornava as elites responsivas e responsáveis por seus atos; os estudiosos de Cambridge associam a ativa participação popular no pensamento de Maquiavel primeiramente com conquistas militares, em contraste com a política doméstica; eles igualam, inapropriadamente, sua críticas à nobreza com aquelas do povo, debilitando, por conseqüência, o papel proeminente que Maquiavel atribui ao povo como "guardiōes da liberdade"; eles enfocam suas definiçôes abstratas de liberdade às expensas de suas recomendações relativas a políticas específicas sobre como mantê-la; os estudiosos de Cambridge usam Maquiavel para formular uma definição de liberdade que se opõe à opressão política de vários tipos, mas que é, em verdade, fraca com respeito à dominação social; e permanecem amplamente em silêncio sobre o tipo de dominação doméstica do povo pelas elites, algo plenamente consoante à teoria republicana e muito freqüentemente perpetrada na prática republicana (McCormick, 2003, p. 636).

McCormick sugere que a recuperação do pensamento político de Maquiavel teria mais utilidade para a superação dos dilemas da teoria democrática contemporânea do que para reviver a tradição republicana. Ele prefere dar ênfase às tendências pró-plebéias do florentino, realizando um esforço para trazê-lo para o leito do radicalismo democrático contemporâneo. Mas cabe aqui a pergunta: seria esse Maquiavel democrático um "Maquiavel 
contra o republicanismo", como chega a sugerir McCormick? Não creio. O fato é que, descontado o tom polêmico da maneira de o autor colocar o problema, pode-se dizer que sua interpretação de Maquiavel é compatível com o ideal de uma república com intensa participação popular, uma república em que o ideal do civismo, aristocrático por definição, não se sobreponha ao ideal do plebeísmo, calcado na idéia de extensão da cidadania. ${ }^{17}$ Afinal, como o próprio McCormick acaba por reconhecer, ao menos para os padrōes de sua época, "Maquiavel defende uma república, sem qualquer ambigüidade, dominada pelo povo" (McCormick, 2001, p. 311, grifo meu).

Em que consistiria a contribuição da "democracia maquiaveliana” para a teoria democrática contemporânea? Para McCormick, Maquiavel reúne num só modelo os pontos fortes dos dois principais pólos do debate teórico atual. "Assim como nas abordagens formal ou minimalista, ele especifica e justifica mecanismos eleitorais para o controle da elite; e de modo similar a abordagens de cultura cívica e participatória recentes, ele encoraja modos mais diretos e robustos de engajamento popular com a política”. Ainda mais importante: "ao combinar os pontos fortes de cada abordagem, Maquiavel supera suas respectivas debilidades" (Idem, p. 297). O grande problema das democracias contemporâneas estaria na dificuldade de o povo soberano manter sob algum controle os representantes encastelados nos postos de governo. Nesse sentido, a democracia maquiaveliana poderia ser considerada uma teoria da accountability, uma vez que ela estabelece os argumentos e indica os mecanismos para um sensível incremento do grau de controle popular sobre as elites responsáveis pelas decisões públicas.

Diferentemente da miopia sociológica da maior parte das teorias da democracia em voga, Maquiavel concebe a operação das instituiçõos políticas republicanas em estreita associação com sua visão da inevitabilidade das divisões e dos conflitos de classe. Desse modo, o povo como categoria sociopolítica não se desvincula do povo como categoria socioeconômica, diversamente do que se encontra nos "arquitetos constitucionais modernos", os quais "claramente se recusaram a projetar instituiçóes que reconhecessem, atendessem, ou refletissem distinções socioeconômicas" (McCormick, 2006, p. 159). Maquiavel claramente exclui os cidadãos ricos e poderosos da categoria de povo porque os desejos e os interesses que estes perseguem são não apenas diferentes, mas também opostos aos desejos e interesses dos cidadãos comuns. Os primeiros desejam dominar e expandir o seu domínio; os segundos desejam não ser dominados. Em Maquiavel, a clivagem entre ricos e pobres traduz-se, em termos sociopolíticos, na clivagem entre a nobreza e o povo $\mathrm{e}$, em termos institucionais, na clivagem entre os senadores e os tribunos. Em vez de perseguir formas institucionais destinadas a neutralizar a visibilidade da divisão entre ricos e pobres, Maquiavel projeta instituiçôes que tornam ainda mais nítida tal divisão. Para McCormick, uma das mais profundas lições de Maquiavel "é a de que as inevitáveis disparidades de poder entre grandi e popolo dentro das repúblicas deveriam ser institucionalmente arranjadas de modo a tornar este mais, e não menos, cônscio disso, e, talvez, motivá-lo a tentar ativamente minimizar tais disparidades"(Idem, ibidem).

Para McCormick, os neo-republicanos não se descuidam de chamar a atenção para a teoria maquiaveliana da diferença dos "humores" dos "grandes" e do povo. Todavia, na análise do conceito de liberdade, eles permanecem a meio-caminho das conclusões do próprio Maquiavel. Embora atentem para o fato de que Maquiavel considerava as divisões sociais a principal causa da liberdade da república romana, eles tendem a nivelar os interesses e valores das duas classes de cidadãos como se suas respectivas contribuições para a manutenção da liberdade fossem equivalentes. Suficiente atenção é dada por eles ao capítulo 4 do primeiro livro dos Discorsi, mas o que Maquiavel escreve no capítulo seguinte, ainda mais importante para a compreensão de sua concepção de liberdade, é apenas tangencialmente abordado pelos neo-republicanos. Se no capítulo 4 Maquiavel desenvolve a tese do conflito como causa da liberdade, no capítulo 5 ele desenvolve a tese do povo como o "guardião da liberdade" (Maquiavel, 2007a, pp. 23-26).

De fato, tem razão McCormick ao afirmar que os neo-republicanos subestimam esse componente fundamental do conceito de liberdade em Maquiavel. Como vimos, Pocock interpretou a idéia do 
povo como "guardião da liberdade" com a disposição do cidadão-soldado para lutar em defesa da pátria, componente a que Skinner e seus seguidores não chegam a dar um significado especial. Este é sem dúvida um grande trunfo de índole textual no esquema interpretativo de McCormick, uma vez que é impossível não reconhecer o lugar de destaque deste ponto na lógica da argumentação de Maquiavel. A idéia do povo como guardiāo da liberdade consiste numa espécie de coroamento das passagens mais abstratas de Maquiavel sobre o tema. A fonte do dinamismo da liberdade está nos conflitos; a forma institucional da liberdade está nas leis que configuram o governo misto; mas a garantia final, o último recurso para a manutenção da liberdade está no desejo do povo de não ser dominado.

Cabe aqui chamar a atenção para um aspecto inusitado do debate em questão, importante para matizar o grau de inovação da interpretação de McCormick em relação à interpretação de Skinner, Pettit e Viroli sobre a concepção maquiaveliana de liberdade. Da mesma forma que esses autores, o teórico norte-americano observa que o núcleo da liberdade maquiaveliana é a noção de não-dominação. Pettit, mais do que qualquer outro, esforçou-se para dar corpo a tal concepção de liberdade, indicando seus princípios teóricos e suas dimensões institucionais. No entanto, a idéia de liberdade como não-dominação, que em Maquiavel se encontra claramente relacionada com um desejo do povo, assume, em Pettit, uma forma mais difusa, aplicando-se a diferentes estruturas de dominação, não necessariamente vinculadas à dominação de classe. A despeito do que provavelmente pensaria McCormick sobre sua própria originalidade, podemos dizer que o conceito de liberdade que ele atribui a Maquiavel pode ser compreendido no conceito de não-dominação refinado por Pettit. A importante diferença consiste no fato de que McCormick, justamente por seguir mais adiante na análise do próprio Maquiavel, vê a idéia de não-dominação com maior grau de especificidade, evitando a argumentação muitas vezes excessivamente abstrata do filósofo irlandês sobre o tema. O que é específico na idéia de nãodominação é que ela é relativa ao desejo do povo de ser livre, de não ser dominado.
A crença maquiaveliana de que reside no povo a "guarda da liberdade" não deve ser interpretada em termos românticos, como se o povo fosse o repositório das boas intençôes da humanidade. McCormick está atento à explicação de Maquiavel de que a maior disposição dos cidadãos comuns para proteger a liberdade reside no fato de que "não podendo eles mesmos apoderar-se dela, não permitem que outros se apoderem" (Maquiavel, 2007a, p. 24).

A esta altura, a questão que se coloca não é tanto sobre como definir a idéia de liberdade, mas sim a de saber quais as formas institucionais favoráveis à sua preservação e expansão. A "democracia maquiaveliana”, forma institucional derivada da idéia de liberdade como não-dominação, não pode prescindir de uma variedade de mecanismos mediante os quais o povo mantém sob estrito controle os movimentos da elite, sempre inclinada à expansão de seu próprio domínio.

Nos textos de Maquiavel, especialmente nos Discorsi, um amplo leque de opções institucionais abre-se para exemplificar os modos pelos quais o povo pode controlar as elites, elevando assim os níveis de accountability no sistema político. McCormick destaca três estratégias institucionais para viabilizar a "democracia maquiaveliana": a combinação de sorteios com os mecanismos eleitorais para a escolha de magistrados; a criação de instituições representativas dos cidadãos comuns inacessíveis aos cidadãos ricos ou aos seus agentes; a instituição de “julgamentos políticos”, em que os juízes são todos os cidadãos.

O autor assinala a distância que separa o modelo republicano idealizado por Maquiavel dos modelos constitucionais das repúblicas modernas e contemporâneas. Estas últimas procuram assegurar a responsividade de representantes e governantes de três diferentes formas: pela via do processo de punição e recompensa eleitoral; por meio do mecanismo institucional de separação e contraposição de poderes; e, em casos extremos, pela ameaça de remoção de elites políticas corrompidas, mediante processo de impeachment conduzido por membros da própria elite. McCormick assinala que Maquiavel ou qualquer outro representante pré-moderno do governo popular veria esse arranjo institucional 
como "estranho, injusto e perigoso" (McCormick, 2006, p. 148), uma vez que

[...] se cidadãos abastados forem livres para se apresentarem como candidatos a todas as magistraturas, se puderem participar de todos os conselhos públicos, e se eleições não qualificadas forem o único expediente que determine a ocupação de um cargo ou a presença em assembléias, os ricos manteriam vantagens políticas distintas e persistentes sobre os cidadãos mais pobres (Idem, ibidem).

Não é preciso uma pesquisa sociológica muito aprofundada para verificarmos a enorme susceptibilidade dos processos eleitorais contemporâneos aos desígnios do poder econômico. Os cidadãos ricos têm, comparativamente, mais recursos para fazer valer seus interesses, candidatando-se eles próprios aos postos de comando político-institucional ou financiando a campanha de seus agentes. Para evitar tal "efeito aristocrático" das eleições, as repúblicas democráticas pré-modernas introduziram a escolha de magistrados por sorteios, não da forma exclusiva (ou quase) das democracias antigas, mas em combinação com a escolha eleitoral. A escolha por sorteio, envolvendo todos os cidadãos, servia como garantia de que as chances dos ricos de serem os escolhidos pela fortuna não seriam maiores do que sua participação percentual na cidadania, assegurando que a distribuição de cargos ocorreria aleatoriamente entre todas as classes de cidadãos. $\mathrm{O}$ mecanismo de sorteio, aliado ao "revezamento regular e freqüente dos cargos oficiais", evitaria que os setores mais ricos pudessem usar seus recursos quer "para aninharem-se eles mesmos num cargo", quer "para influenciar ou determinar a nomeação de sucessores de opiniōes semelhantes ou interesses similares" (Idem, p.149).

Uma estratégia adicional das repúblicas democráticas pré-modernas para assegurar o controle popular sobre as elites governantes consistia no estabelecimento de instituições representativas voltadas exclusivamente para os setores populares. De tais instituiçōes, os setores aristocráticos estavam excluídos por princípio, sendo inelegíveis seus representantes. O exemplo mais notável de uma instituição dessa natureza é o Tribunato da Roma republicana. Em sua narrativa da evolução de Roma para o governo misto, Maquiavel mostra como a plebe romana emprestou seu auxílio à aristocracia para a expulsão dos reis. Porém, tão logo começou a sofrer os abusos dos aristocratas, a plebe retirou-se em massa de Roma, deixando os nobres, que temiam o retorno da realeza, numa situação de fragilidade. A aristocracia solicitou o retorno da plebe, mas esta só atendeu essa solicitação quando lhe foi concedida uma instituição com prerrogativas reais de poder para abrigar seus representantes. Os tribunos, na qualidade de representantes exclusivos do povo, exerciam a função essencial de conter a arrogância dos ricos e poderosos. Suas prerrogativas ante os cônsules e senadores da república lhes permitiam isso. McCormick observa que "na condição de portadores do veto, e de agentes de acusação principais, os tribunos possuíam os meios para bloquear propostas e sançôes de açōes dos cônsules ou senadores" (2001, p. 300). ${ }^{18}$

Por fim, o povo pôde exercer seu controle sobre o comportamento das elites mediante o recurso a amplos "julgamentos políticos", nos quais toda a cidadania podia interferir. McCormick dedica um ensaio inteiro para tratar desse ponto no pensamento de Maquiavel (McCormick, 2007). Em seu exame das instituiçôes e dos costumes romanos, Maquiavel observou com admiração o direito de todo e qualquer cidadão romano acusar de corrupção qualquer magistrado da república. "Tal acusação incitaria uma audiência numa concione, uma assembléia deliberativa informal, ou um julgamento numa das assembléias de voto oficiais (um comitia ou o concilium plebis) que decidia se os acusados deveriam, por exemplo, reter seus cargos, pagar uma multa, ou sofrer exílio" (Idem, p. 387). Não obstante a predileção de Maquiavel por amplos mecanismos de acusação, ele também julgava fundamental que a república se acautelasse contra os caluniadores. Se o povo, reunido nos conciones e nos concillium plebis, concluísse que a acusação era falsa, o caluniador deveria sofrer a mesma pena que sofreria o acusado caso a denúncia fosse verdadeira. Nesse aspecto, a admiração de Maquiavel por Roma era seguida por sua frustração com Florença. "De acordo com Maquiavel, a ausência de acusação, julgamento e procedimentos de apelação legalmente estabelecidos e amplamente po- 
pulares em Florença foi uma das causas principais da instabilidade da república” (Idem, p. 408). As acusações públicas e os julgamentos políticos são essenciais numa república porque são mecanismos que "fornecem um escape para o desabafo ordinário dos 'humores' sociais que são gerados pelo antagonismo de classe". Desse modo, tais mecanismos institucionais "previnem a escalada da violência facciosa”. Aqui, uma vez mais, ainda que sem o reconhecer, McCormick aproxima-se do cerne da visão de Skinner, Pettit e Viroli acerca da importância do marco institucional-legal no republicanismo de Maquiavel. Conforme conclui o teórico norte-americano, "uma república será arruinada se o inevitável conflito entre os grandi - que desejam, acima de tudo, oprimir os outros - e o povo - que deseja, prioritariamente, não ser dominado - manifestar-se extraordinariamente, isto é, extra-institucionalmente ou ilegalmente (Idem, p. 388).

\section{Considerações finais}

O principal objetivo deste artigo foi realizar um exame das distinçôes entre três vertentes teóricas no âmbito do recente republican revival na teoria política contemporânea. De um modo geral, a atenção dos críticos tem se dirigido para as distinções entre republicanismo e liberalismo. Isso faz muito sentido, na medida em que todos os autores aqui examinados apresentam suas visōes da política como alternativas à hegemonia do pensamento liberal. Todavia, decorridas já algumas décadas da emergência da vaga republicana, é tempo de darmos mais atenção à heterogeneidade desse movimento de idéias. A simples oposição do republicanismo ao liberalismo faz as próprias alternativas "republicanas" parecerem mais similares do que elas realmente são.

O objetivo mais específico do artigo foi examinar as distinções no interior do movimento intelectual republicano a partir dos diferentes modos de apropriação da obra de Maquiavel. Todos os estudiosos aqui examinados apóiam-se na herança e na autoridade de Maquiavel para dar forma a suas próprias idéias políticas. Nesse sentido, interessounos mais a obra de Maquiavel como um campo de disputas entre concepçôes rivais de república e de- mocracia do que como um repositório de evidências textuais e contextuais indicativas da intenção do pensador florentino.

As interpretaçôes "neo-aristotélica" e "neoromana" do republicanismo de Maquiavel diferem em aspectos cruciais. A primeira apresenta a virtude cívica (traduzida em termos de virtude militar do povo) como a idéia-força do pensamento político maquiaveliano, ao passo que a segunda enfatiza o funcionamento da estrutura institucional republicana, organizada em torno dos princípios da constituição mista e da contraposição e equilíbrio de poderes. Uma interpretação opera com o conceito de liberdade positiva, enquanto a outra opera com um conceito especial de liberdade negativa. Essa distinção ficou evidente nas interpretações contrastantes de Pocock e Skinner. ${ }^{19}$ Para Pocock, Maquiavel estaria em grande sintonia com o humanismo renascentista de sua época. Como muitos de seus contemporâneos, vinculava a sorte das repúblicas e a existência da liberdade à participação efetiva de cidadãos virtuosos nos negócios públicos. Já para Skinner, a participação seria um dos meios para a liberdade, mas não o único. De nada valeria a participação intensa dos cidadãos se não houvesse boas leis para canalizar toda essa atividade. Subjacente a essa tese, há a idéia de que o corpo social se encontra irrevogavelmente cindido em interesses e valores conflitantes, e que os homens, embora não naturalmente corruptos, tendem à corrupção, e realizarão tal tendência sempre que encontrarem circunstâncias favoráveis corroboradas pelo silêncio da lei. As leis republicanas serviriam para canalizar e equilibrar o conflito social e político, bem como para antepor obstáculos à realização do potencial de corrupção latente em todos os cidadãos, sejam eles ricos ou pobres, nobres ou plebeus.

A terceira interpretação dos textos maquiavelianos aqui examinada prefere compreender o secretário florentino mais no âmbito da tradição democrática moderna do que no âmbito do republicanismo clássico. Contudo, parece-nos mais apropriado compreender a posição do próprio McCormick como uma espécie de radicalização da idéia de liberdade como não-dominação, central na formulação do republicanismo de Pettit e Skinner. Abrandada a polêmica, observa-se que esta mesma concepção de liberdade 
orienta a interpretação de McCormick sobre Maquiavel. Não obstante, ao insistir nas condições sociológicas do ideal da não-dominação e ao descrever com maior grau de detalhamento as instituições políticas que visam dar suporte a tal ideal, McCormick enfatiza a dimensão "plebeísta" deste ideal de liberdade. Para McCormick, a leitura de Maquiavel promovida pelos intérpretes da escola de Cambridge passa ao largo de um ponto fundamental da teoria da liberdade do pensador florentino. Embora Maquiavel realmente defendesse que a constituição do Estado misto representava um meio de evitar que qualquer um dos dois setores sociais fundamentais (o povo e as elites) realizasse sua tendência à corrupção, ele não situava as paixôes e os interesses (os humores) desses setores no mesmo patamar de ameaça à liberdade. Enquanto o desejo das elites consiste em dominar e expandir seu domínio, o desejo do povo consiste basicamente em não ser dominado, sendo este desejo não somente compatível com a liberdade, mas idêntico a ela. É por essa razão que no núcleo do sistema constitucional idealizado por Maquiavel há inúmeros mecanismos destinados a facilitar o controle das elites dirigentes pelo cidadão comum. É tal especificidade institucional das repúblicas democráticas que permite ao povo o exercício de sua mais importante missão constitucional: a "guarda da liberdade".

Com o objetivo de responder a questão formulada no final da seção introdutória deste artigo, procuramos mostrar que os historiadores e teóricos do neo-republicanismo estão assumindo, por intermédio dos textos e da autoridade de Maquiavel, distintas posiçôes normativas nas disputas correntes entre os diversos modelos de organização das instituições políticas nas sociedades democráticas de nossos dias. De um lado, em uníssono, os neo-republicanos posicionam-se como alternativa ao pensamento liberal dominante, que insiste na defesa da "liberdade negativa”, um modo de definir a liberdade como a ausência de toda forma de interferência externa nas escolhas e nas ações dos agentes individuais. Contudo, de outro lado, parece-nos evidente que o consenso negativo que une os neo-republicanos contra o pensamento liberal dominante se revela frágil tão logo é transcendido o momento da crítica do modelo liberal e se inicia o momento da afirmação do modelo republicano. Observando os diferentes enquadramentos que os neo-republicanos dão a conceitos centrais, como o próprio conceito de liberdade, bem como seus desacordos quanto à natureza do acervo institucional adequado a uma república bem ordenada, o analista é levado à conclusão de que está tratando de uma disputa entre diferentes fórmulas políticas que recorrem à longa e multifacetada tradição republicana. No caso em apreço, essa disputa pela tradição desenrola-se de um modo ainda mais interessante, uma vez que as diferentes vertentes neo-republicanas aqui evocadas se apóiam na obra do mesmo autor. Nesse sentido, a obra de Maquiavel foi aqui compreendida mais como um campo de disputas ideológicas, com recursos que podem servir a interpretações rivais, do que como um repositório de fatos e evidências textuais e contextuais à espera do historiador desinteressado.

\section{Notas}

1 Uma recente retomada desta linha de argumentação, num registro ainda mais radical, encontra-se em Dietz (1986). A autora argumenta que a arte do "embuste" (deception) era um componente central da política de Maquiavel, e que ele usara tal arte para induzir Lorenzo de Médici ao fracasso, com vistas a tornar viável a restauração da república. Uma crítica ao modo como Dietz caracteriza a intenção de Maquiavel encontra-se em Langton (1987).

2 Surgida nos contextos acadêmicos anglófonos há três ou quatro décadas, a vaga neo-republicana vem, desde então, se difundindo rapidamente para outras regiōes. Valiosas amostras da recepção do movimento de "retorno ao republicanismo" no contexto acadêmico brasileiro encontram-se nas coletâneas organizadas por Bignotto (2000) e Cardoso (2004).

3 Na introdução de seu mais aclamado livro, Pocock escreve: "quando busco nomear aqueles estudiosos cujas obras têm um significado maior para mim na escrita deste estudo, a presença de Hans Baron vem à tona de modo sublime, ainda que controverso, (e inteiramente sem seu conhecimento prévio) por todo o cenário" (Pocock, 1975, p. ix).

4 No contexto acadêmico de meados do século XX, a narrativa que entroniza John Locke como o grande pai espiritual da revolução norte-americana foi conduzida ao mais elevado nível de refinamento na obra 
de Louis Hartz (1955). Quando Pocock publicou seu The machiavellian moment, já haviam sido publicadas pelos menos duas obras de certa repercussão destinadas tanto à crítica da narrativa hartziana como à promoção de uma abordagem "republicana" para explicar as origens e a identidade da revolução norte-americana (ver Baylin, 1967, e Wood, 1969). Pocock beneficiouse destes estudos, mas foi muito além dos resultados de Baylin e Wood, uma vez que não limitou sua investigação ao contexto norte-americano. Para a historiografia da revolução norte-americana, a contribuição de Pocock consistiu em situar as idéias revolucionárias no âmbito de uma tradição mais ampla, cuja expressão conceitual seria o "momento maquiaveliano".

5 Para uma crítica da leitura que Pocock faz do pensamento político de Aristóteles, ver Nadon (1996).

6 Alguns críticos de Pocock argumentam que "ao consignar o pensamento de Maquiavel a um contexto definido por seu foco num tipo de republicanismo que exalta a participação política a serviço do bem comum, Pocock entorpece os aspectos mais perspicazes da análise política de Maquiavel" (Sullivan, 1992, p. 315).

7 A interpretação pocockiana de Maquiavel e do humanismo cívico tem sido alvo de constantes ataques. No posfácio da segunda edição de The machiavellian moment, Pocock registra, num tom que lhe é pouco habitual, seu incômodo com as atitudes dos historiadores em relação à noção de virtude cívica. Conforme suas palavras: "Percebo na profissão dos historiadores em geral, e entre os historiadores do pensamento político em particular, um baixo nível de tolerância, mesmo após trinta anos, em relação à noção de que a virtude cívica, tal como estudada em 'The Machiavellian Moment', goza de uma história própria; há um desejo razoavelmente constante de diminuí-la ou de diminuir sua presença" (Pocock, 2003a, p. 562).

8 Sobre o debate metodológico desencadeado pelas contribuiçōes de Skinner, ver a coletânea organizada por Tully (1988). Vale ponderar que, de modo geral, os críticos e comentadores da Escola de Cambridge tendem a homogeneizar as concepções sobre o método historiográfico de Skinner e Pocock. Embora ambos mostrem-se muito à vontade sempre que apresentados como membros de uma mesma abordagem metodológica, distinções nada desprezíveis sobre suas respectivas maneiras de apresentar a metodologia adequada à história das idéias não devem ser postas de lado. Sobre tais distinçōes, ver Bevir (2008, capítulo 2).

9 Na literatura recente, o debate entre republicanismo e liberalismo tem recebido considerável atenção. Ver, por exemplo, Patten (1996), Maynor (2002), Larmore (2003), Brennan e Lomaski (2006).

10 Indubitavelmente, nenhum pensador liberal do século XX exerceu tanta influência no debate sobre o conceito de liberdade quanto Isaiah Berlin. Berlin consolida a dicotomia entre liberdade positiva e liberdade negativa advogando que somente a última seria compatível com a natureza pluralista das sociedades modernas, sociedades nas quais nenhuma concepção particular de bem reúne condiçōes para sobrepor-se às demais. A dicotomia sofisticada por Berlin atualiza a dicotomia entre liberdade dos antigos e liberdade dos modernos, apresentada por Benjamin Constant no começo do século XIX (Constant, 1985). Skinner toma como ponto de partida a formulação de Berlin, procurando, contudo, demonstrar que a definição dada pelo teórico liberal ao conceito de liberdade negativa conta com uma história ainda mais antiga, remontando a meados do século XVII. Segundo o historiador de Cambridge, o grande teórico moderno a definir a liberdade em termos de ausência de impedimento externo à ação individual foi Thomas Hobbes. "Hobbes vê dois elementos essenciais no conceito de liberdade humana. Um é a idéia de se possuir um poder ou capacidade subjacente para agir [...]. O outro é a idéia de se estar desimpedido no exercício de tais poderes" (Skinner, 2002b, p. 211). Parece claro que esses dois elementos também estão no núcleo da definição de Berlin do conceito de liberdade negativa. Não é aqui o lugar para questionar a interpretação de Skinner sobre as teses de Berlin. Contudo, vale ressaltar que tem razão Nadia Urbinati quando afirma que Skinner está muito longe de aplicar o rigor contextualista que prescreve em sua metodologia histórica no exame da teoria de Berlin (Urbinati, 2005).

11 Alguns críticos têm questionado a suposição de Skinner de que os autores romanos cultivaram um pensamento independente dos gregos. William Walker, por exemplo, argumenta que "Salústio tem muito mais em comum com Aristóteles do que reivindica Skinner". Segundo ele, "Assim como Aristóteles, Salústio vê o valor das liberdades particulares como derivando do fato de que são precondições para a realização de nossos fins naturais. Assim como Aristóteles, Salústio também vê a lei e a virtude civis como precondiçōes básicas para a existência da liberdade civil. Embora haja diferenças importantes entre Aristóteles e Salústio no que se refere à liberdade civil, há também, pois, similaridades importantes, as quais emprestam apoio considerável à visão de ser de Aristóteles, uma figura fundacional do pensamento político republicano" (Walker, 2006, pp. 240 e 257). 
12 Embora os valores e os objetivos sejam idênticos, os meios propostos por Maquiavel para a realização dos fins republicanos são tão estranhos ao republicanismo clássico que não seria exagero ver na obra do secretário florentino uma "máquina de guerra contra o humanismo cívico" (Bignotto, 1991, p. 231).

13 Conforme Skinner, em relação ao cidadão de uma república, "a lei opera com o fim de canalizar seu comportamento de tal modo que, embora as motivaçōes para a sua ação permaneçam auto-interessadas, suas açốes têm consequiências que, apesar de não intencionadas, são de tal ordem que promovem o interesse público e, por conseqüência, sua própria liberdade individual" (Skinner, 1983, p. 10).

14 Kari Palonen, um dos mais aplicados estudiosos da obra de Skinner, considera um retrocesso o fato de Skinner ter se voltado, sob a influência de Philip Pettit, para os teóricos da commonwealth inglesa do século XVII, abandonando sua abordagem do conceito de liberdade a partir de Maquiavel. Segundo Palonen, ao contrário do que Skinner passou a sugerir mais tarde, Maquiavel não sofria qualquer influência da abordagem jurídica de liberdade, tal como esta aparecia no Digesto das leis romanas. Sua fonte de inspiração teria sido a tradição retórica humanista (Palonen, 1998, pp. 246-247).

15 Sobre as trocas e as influências recíprocas entre a história intelectual de Skinner e a teoria política normativa de Pettit, ver Silva (2008). Embora Skinner tenha começado a se preocupar com a teoria republicana da liberdade pelo menos uma década antes de Pettit, é possível encontrar em seus textos mais recentes inúmeras passagens em que o historiador reconhece o impacto das formulaçóes do filósofo irlandês no redirecionamento de seus estudos sobre o tema. Conforme escreveu recentemente, em análise retrospectiva de sua obra, "embora tenha escrito sobre dependenza e servitù, foi somente com o auxílio da obra pioneira de Philip Pettit que finalmente consegui aclarar, para minha própria satisfação, as características definidoras da teoria que esbocei" (Skinner, 2006, p. 257). Em Liberdade antes do liberalismo, Skinner revê sua crença anterior de que a diferença principal entre a concepção republicana e a concepção liberal de liberdade encontrava-se simplesmente nas condiçôes que deveriam ser cumpridas para a manutenção da liberdade. "Philip Pettit convenceume de que as duas escolas de pensamento de fato discordam sobre (entre outras coisas) o próprio significado de liberdade" (Skinner, 1999, p. 62). Ainda mais recentemente, Skinner (2008) faz outro movimento a favor da convergência de suas formulações com as de Pettit. Em Liberdade antes do liberalismo ele havia sustentado que os pensadores clássicos do republicanismo inglês do século XVII concebiam a liberdade individual tanto como ausência de dependência da vontade arbitrária de terceiros, quanto como ausência de interferência efetiva nas escolhas que um agente está apto a realizar. Pettit já havia solicitado a Skinner um esforço de simplificação do conceito de liberdade republicana (Pettit, 2002), sugerindo-lhe manter como núcleo definidor do conceito somente a primeira condição. A solicitação foi atendida por Skinner, com a justificativa de que, "como Pettit corretamente observa, a capacidade para engajar-se em interferência arbitrária depende da posse prévia de poder arbitrário". E é "esta presença subjacente de tal poder que constitui a afronta fundamental à liberdade" (Skinner, 2008).

16 Pocock, com efeito, é um desses autores. Seu caso contra a concepção jurídica da liberdade vem sendo substanciado em inúmeros ensaios recentes. Para Pocock, a "lei [...] é antes do império do que da república” (Pocock, 2003b, p. 86). O tipo de liberdade que o cidadão desfruta conforme a linguagem da jurisprudência "não é suficiente para fazer dele um cidadão no sentido grego, um cidadão que governa e é governado". Pocock retoma a célebre dicotomia entre liberdade negativa e liberdade positiva para afirmar que a "apresentação jurídica da liberdade era [...] negativa", e que o "vocabulário republicano empregado por dictatores, retóricos e humanistas articulava a concepção positiva de liberdade: sustentava que o homo, $\mathrm{o}$ animale politicum, era constituído de tal forma que sua natureza só se completava em uma vita activa, praticada em um vivere civile" (Pocock, 2003b, p. 87).

17 Para uma análise das distinçôes entre o "civismo" e o "plebeísmo" como ideais normativos dos Estados democráticos, ver Araújo (2000).

18 McCormick propõe a inclusão, na constituição dos Estados Unidos, de uma instituição semelhante ao tribunato romano, mas com funçôes mais adaptadas aos dias de hoje. Seus 51 ocupantes seriam escolhidos por sorteio para um mandato não renovável de um ano. Eles seriam escolhidos entre os cidadãos maiores de 25 anos, cuja renda familiar anual não fosse superior a U\$ 345.000 (McCormick, 2006, p. 160).

19 As distinções entre a visão de Pocock e a de Skinner passaram a ser apontadas recentemente por alguns críticos (por exemplo Geuna, 2006, p. 54, e Castiglione, 2005, p. 458). Nos últimos anos, é possível observar nos textos dos próprios autores da escola de Cambridge manifestaçōes cada vez mais enfáticas sobre as diferenças relevantes entre suas respectivas interpretações da tradição republicana. Ver Pocock (2003a, pp. 556557; 2006, pp. 41ss.) e Skinner (2006, p. 257). 


\section{BIBLIOGRAFIA}

ARAÚJO, Cícero. (2000), "República e democracia”. Lua Nova, 51: 5-30.

ARENDT, Hannah. (1999), O que é a Política? 2 ed. Rio de Janeiro, Bertrand Brasil.

BAYLIN, Bernard. (1967), The ideological origins of the American revolution. Cambridge, Massachusetts, Harvard University Press.

BARON, Hans. (1961), "Machiavelli: the republican citizen and the author of "The Prince". The English Historical Review, 76 (299): 217-253. . (1966), The crisis of the early Italian Renaissance. Princeton, Princeton University Press.

BERLIN, Isaiah. (2002), "Dois conceitos de liberdade”, in H. Hardy e R. Hausheer (orgs.), Isaiah Berlin: estudos sobre a humanidade. São Paulo, Companhia das Letras.

BEVIR, Mark. (2008), A lógica da história das idéias. São Paulo, Edusc.

BIGNOTTO, Newton. (1991), Maquiavel republicano. São Paulo, Loyola.

(org.). (2000), Pensar a República. Belo Horizonte, Editora da UFMG.

BRENNAN, Geoffrey. \& LOMASKI, Loren. (2006), "Against reviving republicanism". Politics, Philosophy \& Economics, 5 (2): 221-252.

CARDOSO, Sergio. (org.). (2004), Retorno aо republicanismo. Belo Horizonte, Editora da UFMG.

CASTIGLIONE, Dario. (2006), "The republicanism and its legacy". European Journal of Political Theory, 4 (4): 453-465.

CHABOD, Federico. (1958), Machiavelli \& the Renaissance. Cambridge, Massachusetts, Harvard University Press.

CONSTANT, Benjamin. (1985), "Da liberdade dos antigos comparada à dos modernos". Filosofia Politica, 2: 9-25.

DIETZ, Mary. (1986), “Trapping the Prince: Machiavelli and the politics of deception". American Political Science Review, 80 (3): 777-791.

GEUNNA, Marco. (2006), "Skinner, pre-humanistic rhetorical culture and Machiavelli, in Annabel Brett, James Tully e Holly HamiltonBleakley (eds.), Rethinking foundations of modern political thought, Cambridge, CUP.
HARTZ, Louis. (1955), The liberal tradition in America. Nova York, Harcourt.

LAGTON, John. (1987), "Machiavelli's paradox: trapping or teaching the Prince". American Political Science Review, 81 (4): 1277-1288.

LARMORE, Charles. (2003), "Liberal and Republican conceptions of freedom". Critical Review of International Social \& Political Philosophy, 6 (1): 96-119.

MAQUIAVEL, Nicolau. (1998), O Príncipe. São Paulo, Martins Fontes.

. (2007a), Discursos sobre a primeira década de Tito Livio. São Paulo, Martins Fontes. (2007b), História de Florença. São Paulo, Martins Fontes.

MAYNOR, John. (2002), "Another instrumental republican approach?”. European Journal of Political Theory, 1 (1): 71-89.

MCCORMICK, John P. (1993), "Addressing political exception: Machiavelli's "accidents" and the mixed regime". The American Political Science Review, 87 (4): 888-900.

(2001), "Machiavellian democracy: controlling elites with ferocious populism". American Political Science Review, 95 (2): $297-$ 313.

(2003), "Machiavelli against republicanism on Cambridge School's "Guicciardinan Moments". Political Theory, 31 (5): 615643.

. (2006), "Contain the wealthy and patrol the magistrates: restoring elite accountability to popular government". American Political Science Review, 100 (2): 297-313.

(2007), "Machiavelli's political trials and 'Free Way of Life'". Political Theory, 36 (4): 385-411.

NAJEMY, John. (1996), "Baron's Machiavelli and renaissance republicanism". The American Historical Review, 101 (1): 119-129.

NADON, Christian. (1996), "Aristotle and the Republican paradigm: a reconsideration of Pocock's Machiavellian moment". The Review of Politics, 58 (4): 677-698

PALONEN, Kari. (1998), "Liberty is too precious a concept to be left to the liberals". Finish Yearbook of Political Thought, 2: 243-260. 
PATTEN, Alan. (1996), "The republican critique of liberalism". British Journal of Political Science, 26 (1): 25-44.

PETTIT, Philip. (1999), Republicanism: a theory of freedom and government. Oxford, Oxford University Press.

. (2002), "Keeping republican freedom simple”. Political Theory, 30 (3): 339-356.

POCOCK, John. (1975), The machiavellian moment: florentine political thought and the Antlantic Republican traditition. Princeton, NJ, Princeton University Press. . (2003a), "Aftewords", in

The machiavellian moment: florentine political thought and the Antlantic Republican traditition. Princeton, NJ, Princeton University Press. (2003b), Linguagens do ideário politico. São Paulo, Edusp. . (2006), "Foundations and moments", in Annabel Brett, James Tully e Holly Hamilton-Bleakley (eds.), Rethinking foundations of modern political thought. Cambridge, CUP.

RODGERS, Daniel. (1992), "Republicanism: the career of a concept". The Journal of American History, 79 (1): 11-38.

ROUSSEAU, J-J. (s/d), O contrato social e outros escritos. São Paulo, Cultrix.

SHAW, Carl. (2003), "Quentin Skinner on the proper meaning of Republican Liberty." Politics, 23 (1): 46-56.

SILVA, Ricardo. (2008), "Liberdade e lei no neorepublicanismo de Skinner e Pettit”. Lua Nova, 74: 151-194.

SKINNER, Quentin. (1983), "Machiavelli on the maintenance of liberty". Politics, 18 (2): 3-15. (1984), "The idea of negative liberty: philosophical and historical perspectives", in Q. Skinner, R. Rorty e J. B. Schneewind (eds.), Philosophy in history, Cambridge, CUP.

. (1988), "Meaning and understanding in the history of ideas", in James Tully (ed.), Meaning and context: Quentin Skinner and his critics, Cambridge, Polity Press.

. (1990a), "Machiavelli and the prehumanist idea of freedom", in Q. Skinner, Maurizio Viroli e Gisela Bock, Machiavelli and republicanism, Cambridge, CUP.
. (1990b), "The republican ideal of political liberty”, in Q. Skinner, Maurizio Viroli e Gisela Bock, Machiavelli and republicanism, Cambridge, CUP.

(1999), A liberdade antes do liberalismo. São Paulo, Editora da Unesp. (2002a), Visions of politics. Vol. 2: Renaissance virtues. Cambridge, Cambridge University Press.

. (2002b), Visions of politics. Vol. 3: Hobbes and the civil law. Cambridge: Cambridge University Press.

. (2006), "Surveying the Foundations: a retrospect and reassessment", in Annabel Brett, James Tully e Holly Hamilton-Bleakley (eds.), Rethinking foundations of modern political thought. Cambridge, CUP.

. (2008), "Freedom as the absence of arbitrary power", in Cecile Laborde e John Maynor (eds.), Republicanism and political theory, Londres, Blackwell.

STRAUSS, Leo. (1958), Thoughts on Machiavelli. Glencoe, Free Press.

SULLIVAN, Vickie B. (1992), "Machiavelli's momentary "Machiavellian Moment": a reconsideration of Pocock's treatment of the Discourses". Political Theory, 20 (2): 309-318.

TULLY, James (ed.). (1988), Meaning and context: Quentin Skinner and his critics. Cambridge: Polity Press.

URBINATI, Nadia. (2005), "The historian and the ideologist". Political Theory, 33 (1): 89-95.

VIROLI, Maurizio. (1990), "Machiavelli and the republican idea of politics", in Q. Skinner, Maurizio Viroli e Gisela Bock, Machiavelli and republicanism, Cambridge, CUP.

(1992), From politics to reason of State. Cambridge, CUP.

. (1998), Machiavelli. Oxford, OUP. (2002), O sorriso de Nicolau. São Paulo, Estação Liberdade.

WALKER, William. (2006), "Sallust and Skinner on civil liberty". European Journal of Political Theory, 5 (3): 237-259.

WOOD, Gordon. (1969), The creation of the American Republic, 1776-1787. Chapel Hill, University of North Carolina Press. 


\section{MAQUIAVEL E O CONCEITO \\ DE LIBERDADE EM TRÊS \\ VERTENTES DO NOVO REPUBLICANISMO}

\section{Ricardo Silva}

Palavras-chave: Maquiavel; Neorepublicanismo; Liberdade; Democracia.

As idéias de Maquiavel vêm sendo radicalmente reinterpretadas no âmbito do atual republican revival na história intelectual e na teoria política. O "conselheiro de tiranos" e mestre da dissimulação vai dando lugar ao patriota abnegado e ao filósofo voltado à causa da liberdade e à defesa do bem público. Todavia, o Maquiavel republicano que emerge da crítica à interpretação tradicional ainda não apresenta uma face definida e estável. Em que consiste o núcleo do republicanismo maquiaveliano? Mobilizando uma série de intérpretes recentes de Maquiavel, este artigo examina, comparativamente, três modelos de interpretação das idéias políticas do florentino.

\section{MACHIAVELLI AND THE CONCEPT OF LIBERTY IN THREE BRANCHES OF THE NEW REPUBLICANISM}

\section{Ricardo Silva}

Keywords: Machiavelli; Neo-republicanism; Liberty; Democracy.

Machiavelli's ideas have been radically re-interpreted in the scope of the current republican revival both in intellectual history and political theory. The "advisor to tyrants" and master of disguise has been replaced by the selfless patriot and the philosopher dedicated to the cause of freedom and to the defense of the commonwealth. Nevertheless, the republican Machiavelli that emerges from the criticism to the traditional interpretation still doesn't have stable and well defined features. What does the nucleus of the $\mathrm{Ma}$ chiavellian republicanism consist of? By mobilizing a series of recent interpreters of Machiavelli, this article examines, in a comparative manner, three interpretation models of the Florentine's political ideas.

\section{MACHIAVEL ET LE CONCEPT DE LIBERTÉ SELON TROIS VERSANTS DU NOUVEAU RÉPUBLICANISME}

\section{Ricardo Silva}

Mots-clés: Machiavel; Néo-républicanisme; Liberté; Démocratie.

Les idées de Machiavel subissent une radicale réinterprétation dans le cadre de l'actuel republican revival dans l'histoire intellectuelle et dans la théorie politique. Le "conseiller de tyrans" et maître de la dissimulation cède place au patriote abnégué et philosophe engagé dans la cause de la liberté et de la défense du bien public. Néanmoins, le Machiavel républicain qui émerge de la critique relative à l'interprétation traditionnelle ne présente pas encore de profil défini et stable. En quoi consiste le noyau du républicanisme selon Machiavel ? Cet article examine, de façon comparative et par la mobilisation d'une série d'interprètes récents de $\mathrm{Ma}$ chiavel, trois modèles d'interprétation des idées politiques du florentin. 